medRxiv preprint doi: https://doi.org/10.1101/2021.06.24.21258773; this version posted June 28, 2021. The copyright holder for this preprint (which was not certified by peer review) is the author/funder, who has granted medRxiv a license to display the preprint in perpetuity.

It is made available under a CC-BY-NC-ND 4.0 International license .

\title{
1 Disease Triangle Dynamics of Coccidioidomycosis in Northern Arizona
}

2

3 4 Northern Arizona, which considers the complex interaction between host, pathogen and

5

Article Summary Line: Our work is the first description of the Valley fever disease triangle in environment in the region. Our data suggests that the prevalence of diagnosed cases is rising in the region, some of which are extreme enough to necessitate hospitalization. We present the first evidence of Coccidioides spp. in Northern Arizona soils, suggesting that the pathogen is maintained in the local environment. Until disease prevention is an achievable option via vaccination, we anticipate that incidence of Valley fever will rise in the area. Therefore, enhanced disease awareness and screening for the coccidioidomycosis is vital to the communities of Northern Arizona.

Heather L. Mead ${ }^{1,2}$, Dan Kollath ${ }^{1}$, Marcus de Melo Teixeira ${ }^{3}$, Chandler C. Roe ${ }^{1}$, Paul K. Keim ${ }^{1}$, Carmel Plude ${ }^{2}{ }_{4}$, Joel Terriquez ${ }^{4}$, Nivedita Nandurkar ${ }^{4}$, Chelsea Donohoo ${ }^{5}$, Brettania L.W.

$\mathrm{O}^{\prime}$ Connor ${ }^{6}$, Bridget M. Barker ${ }^{*}$

${ }^{1}$ Pathogen and Microbiome Institute, Northern Arizona University, Flagstaff, AZ. 86011. U.S.A

${ }^{2}$ Translational Genomics Research Institute (TGen), Phoenix and Flagstaff, AZ. USA

${ }^{3}$ Faculty of Medicine, University of Brasilia, Brasilia. Brazil

${ }^{4}$ Northern Arizona Healthcare, Flagstaff, AZ. 86001. U.S.A.

${ }^{5}$ Coconino County Health Department, Flagstaff, AZ. 86004. U.S.A.

${ }^{6}$ Department of Health Sciences Northern Arizona University, Flagstaff, AZ. 86011. U.S.A.

*Corresponding author

NOTE: This preprint reports new research that has not been certified by peer review and should not be used to guide clinical practice. 
medRxiv preprint doi: https://doi.org/10.1101/2021.06.24.21258773; this version posted June 28, 2021. The copyright holder for this preprint (which was not certified by peer review) is the author/funder, who has granted medRxiv a license to display the preprint in perpetuity.

It is made available under a CC-BY-NC-ND 4.0 International license .

\section{Abstract}

Coccidioides species are the etiological agent of Valley fever (Vf). Disease ranges from

pneumonia to extrapulmonary infection. If diagnosis is delayed or missed, the risk of severe disease increases. We investigate the disease triangle (intersection of pathogen, host, and environment) of $\mathrm{Vf}$ in Northern Arizona, where the risk of acquiring the disease is lower but prevalent and rising. We inspect reported and hospitalized cases of VF hosts. Then assess pathogen origin by comparing Northern Arizona clinical isolates to isolates from other regions. Lastly, we survey Northern Arizona soils for evidence of Coccidioides. We found that cases of Vf are increasing some requiring hospitalization. The Northern Arizona Coccidioidies isolates were genetically related to Southern Arizona populations. However, we detected Coccidioides DNA in Northern Arizona soils. We expect that cases will continue to increase and suggest increased awareness and screening for the disease is crucial to limit severe illness in Northern Arizona.

37 Keywords: coccidioidomycosis, Valley fever, disease triangle, fungal infection, diseases of southwestern united states, endemic fungi, Northern Arizona

\section{Introduction}

The disease triangle is a concept which includes the interaction between host, pathogen and the

41 environment. Infectious diseases can emerge when a vulnerable host, virulent pathogen and

42 favorable environmental conditions complete the triangle (1). This framework has been applied

43 to a wide variety of diseases that affect both plants and animals $(2,3)$. Lessons can be learned

44 from the famous potato famine in Ireland and applied to protect future crop security (1).

45 Similarly, during the global COVID-19 pandemic these interactions are under scrutiny to determine and monitor the animal reservoir of the novel SARS-CoV-2 virus (4-6). Clearly, the 
medRxiv preprint doi: https://doi.org/10.1101/2021.06.24.21258773; this version posted June 28, 2021. The copyright holder for this preprint (which was not certified by peer review) is the author/funder, who has granted medRxiv a license to display the preprint in perpetuity.

It is made available under a CC-BY-NC-ND 4.0 International license .

47 disease triangle is a critical perspective for considering infectious diseases and predicting future implications for human health. One environmentally acquired fungal infection of concern is coccidioidomycosis (Valley fever), caused by two Coccidioides species. Alarmingly, cases of this disease are increasing nationwide (7-9).

Valley fever in humans can be self-limited, requiring little to no medical care, or chronic

52 causing years of treatment and/or life-long symptoms (10). Infection occurs when aerosolized environmental arthroconidia are inhaled by a susceptible host, thus, Valley fever typically manifests as a respiratory infection which presents as asymptomatic, acute or fibrocavitary chronic pneumonia (11). In severe cases, dissemination to extrapulmonary sites, such as the skeletal or the central nervous system occurs and requires life-long antifungal treatment $(10,11)$.

57 This broad range of clinical symptoms makes determining yearly case burden challenging, but estimates range from 150,000 - 350,000 cases/year in the United States $(8,12)$. Fortunately, for many patients the disease can be asymptomatic or present as self-limited pneumonia not requiring clinical intervention. Unfortunately, for symptomatic patients, misdiagnosis occurs

61 frequently, which contributes to the inappropriate use of antibiotics or long delays in correct treatment $(9,13)$. Therefore, reported cases underestimate actual cases due to individuals not seeking medical care, misdiagnosis and underreporting $(8,14)$. In known endemic regions, 64 approximately $30 \%$ of community acquired pneumonia cases are known to be due to Valley 65 fever, but patients are infrequently tested for Valley fever and thus not reported (15-17).

66 Preventing infection is difficult because even at individual locations the occurrence of detectable 67 airborne fungal particles can fluctuate daily, consequently any public health warnings based on detection would delayed $(18,19)$. The underlying mechanisms which contribute to host 69 susceptibility are elusive, preventing the identification of all highly susceptible individuals as a 
medRxiv preprint doi: https://doi.org/10.1101/2021.06.24.21258773; this version posted June 28, 2021. The copyright holder for this preprint (which was not certified by peer review) is the author/funder, who has granted medRxiv a license to display the preprint in perpetuity.

It is made available under a CC-BY-NC-ND 4.0 International license .

70 prevention strategy (20). Lastly, despite decades of research, a viable vaccine has not been

71 identified $(21,22)$. Therefore, an important part of combating this disease currently requires

72 defining the patterns of host susceptibility, pathogen virulence potential and environmental

73 requirements which support the lifecycle. Which approach contributes towards improved

74 awareness among community members, healthcare professionals and infectious disease

75 researchers.

Retrospective studies based on medical records are typically used to identify host specific

77 factors which contribute to the Valley fever disease triangle $(16,17,23-26)$. This approach is

78 helpful but incomplete as asymptomatic or mild cases that did not require a medical visit are not

79 included. Nevertheless, these strategies have identified several factors which increase host

80 disease susceptibility. Substantial evidence shows there are differences in risk of Valley fever

81 disease severity by race. Individuals of African or Filipino descent are a recognized risk group

82 for severe disease, in particular disseminated infection (26). Recently, Native American

83 populations have been suggested to have increased dissemination and hospitalization rates (27).

84 The underlying mechanisms responsible for increased disease vulnerability are undefined (28).

85 These observations are complicated by the uneven distribution of races in endemic areas, uneven sample sizes and the potential effect of socioeconomic and other underlying factors. These

87 complications do not nullify the indication of increased risk among specific populations, but rather validate the need for in-depth studies which consider these aspects (29). Lastly, while many fungal diseases are restricted to immunocompromised individuals, coccidioidomycosis occurs in seemingly healthy individuals as well which could be due to undescribed host factors

91 (30-32). In general, many host specific aspects which dictate Valley fever disease outcomes are undefined or incomplete, which prevents identifying all high-risk populations $(9,25)$. 
medRxiv preprint doi: https://doi.org/10.1101/2021.06.24.21258773; this version posted June 28, 2021. The copyright holder for this preprint (which was not certified by peer review) is the author/funder, who has granted medRxiv a license to display the preprint in perpetuity.

It is made available under a CC-BY-NC-ND 4.0 International license .

The evolution of a host-specific lifecycle, which is distinct from the environmental

94 lifecycle, contributes to Coccidioides ' virulence potential causing disease in humans and other

95

96

97

98

99

100

101

102

103

104

105

106

107

108

109

110

111

112 mammals (33). When the environmental fungal arthroconidia (asexual spore structure) are

inhaled by a mammal, they swell into large structures called spherules which are uniquely

adapted for survival and proliferation in the host $(34,35)$. These fungi have developed

thermotolerant strategies to survive at high temperatures, such as those encountered in the human

body, subsequently increasing pathogenic potential (36). In addition, genomic analyses suggest

that in comparison to common ancestors Coccidioides experienced a reduction in genes needed

to degrade plant material, a common nutrition source for many fungi, and gained the ability to

degrade a variety of animal proteins (37). Molecular systematics and taxonomical studies have

determined that the Coccidioides genus is comprised of two species, C. immitis and C. posadasii

$(38,39)$. Both of these species create the host specific endosporulating spherule structure, that is

not observed in other dimorphic fungi (33). Each species has defined subpopulations with

substantial genetic variation (40-42). Currently, it is unknown if virulence or the ability to cause

disease varies among strains beyond what has been observed in mice or in dated literature (30,

43-46). So far, no specific allelic distributions of fungal virulence phenotypes are associated with

specific disease symptoms. This is in part because little work has been conducted in this area,

though variation in virulence among isolates of Coccidioidies has been suggested $(43,45,47)$.

This missing and crucial information specific to virulence potential could explain the observed

disparity in disease manifestation among individuals and should be investigated.

The environmental niche which supports existence of Coccidioides has not been

completely defined but it is hypothesized that the fungi co-evolved with desert mammals, such as

rodents $(48,49)$. Thus, the pathogen can frequently be detected in the tissue of wild mammals, 
medRxiv preprint doi: https://doi.org/10.1101/2021.06.24.21258773; this version posted June 28, 2021. The copyright holder for this preprint (which was not certified by peer review) is the author/funder, who has granted medRxiv a license to display the preprint in perpetuity.

It is made available under a CC-BY-NC-ND 4.0 International license .

burrows, or archeological sites that are likely enriched with animal-derived organic matter (39, 50-53). In these situations, it is suggested that the fungi exist as mammalian endozoans which survive within the host without causing symptoms and benefit by having direct access to nutrition upon host demise (48). The known environmental distribution of the pathogen includes arid zones of Latin America, ranging from Mexico to Argentina and the southwestern United States $(40,54)$. Recently, the recognized range of the pathogen expanded with locally acquired cases occurring in northwestern states, such as Washington $(55,56)$. Alarmingly, the environmental distribution of Coccidioides is predicted to continue to expand in response to climate variability $(57,58)$. Regions of the southwest that were not traditionally considered endemic will likely serve as suitable habitat for the pathogen in the near future and subsequently it is expected that cases of Valley fever will continue to rise (59).

Historically, Arizona has reported the highest number of diagnosed cases of Valley fever nationwide each year, except in 2018 when Arizona was surpassed by California $(7,9)$. In moderately or suspected endemic regions such as Northern Arizona, the risk of acquiring disease is lower than in established endemic regions, but still prevalent (60). Subsequently, infection is often attributed to travel or prior residence in highly endemic regions. Because the risk of Valley fever is lower across Northern Arizona compared to highly endemic counties of southern Arizona there is potential that diagnosis can be delayed or missed due to lack of awareness and testing (61). Northern Arizona encompasses a third of the state and is divided into five counties, Mohave, Yavapai, Coconino, Apache and Navajo (Figure 1). As with the rest of the state, the incidence of new cases in Northern Arizona is on the rise $(62,63)$. However, data on patients/cases from the region is often grouped with the rest of the state, with most discussion focused on the southern counties Maricopa, Pima and Pinal, with the highest proportion of 
medRxiv preprint doi: https://doi.org/10.1101/2021.06.24.21258773; this version posted June 28, 2021. The copyright holder for this preprint (which was not certified by peer review) is the author/funder, who has granted medRxiv a license to display the preprint in perpetuity.

It is made available under a CC-BY-NC-ND 4.0 International license .

139 reported cases. The environmental factors and potential host population demographics in

140 Northern Arizona are very different from counties to the south. The region is predicted to further

141 support the pathogen's survival in the near future, but little focus has been placed on the current

142 disease burden of the region (58).

143 Herein, we conduct the first focused investigation of coccidioidomycosis in humans in

144 Northern Arizona. We investigate susceptible populations, origins of infection and the potential

145 for the environment to support the pathogen. Our goal is to document the region-specific

146 implications for human health in regard to Valley fever, providing a reference for future

147 investigations and public health awareness campaigns.

\section{Methods}

149 This project utilized four data sources. 1) Public health records to capture reported Valley fever

150 in Northern Arizona counties between year-year. 2) Hospital chart data to capture in patient

151 Valley fever trends at Northern Arizona Healthcare 3) Genomic DNA from clinical isolates

152 obtained at the Northern Arizona Healthcare. 4) DNA extracted from soil in Northern Arizona

153 counties.

154 1) Public Health records: Yearly, county case reports (2017, 2018 and 2019) and historical

155 averages (2012-2016) per 100,000 population were accessed through the Arizona Department of

156 Health Services (AZDHS) website.

157 2) Hospital Records: A retrospective chart review was performed to identify all in-patients that

158 were screened for Valley fever during an 18-month period (7/1/17-12/31/18) at the Flagstaff

159 location of Northern Arizona Healthcare. Screening was defined as when a patient was subjected

160 to Valley fever evaluations through x-ray, titer or complement fixation serological diagnostics.

161 Confirmed positive diagnoses were defined as; positive IgM, titer $>1.8$. These confirmed positive 
medRxiv preprint doi: https://doi.org/10.1101/2021.06.24.21258773; this version posted June 28, 2021. The copyright holder for this preprint (which was not certified by peer review) is the author/funder, who has granted medRxiv a license to display the preprint in perpetuity.

It is made available under a CC-BY-NC-ND 4.0 International license .

cases were reviewed by the infectious disease department to definitively confirm diagnosis. Individual medical records with confirmed coccidioidomycosis cases were further investigated for demographic and comorbidity information.

3) Fungal Isolates: The fungal clinical isolates were previously collected and stored under IRB No. 764034 as part of the Northern Arizona University Biobank study with Northern Arizona Healthcare. For this study, these isolates (Supplemental Table 1) were transferred to the Pathogen and Microbiome Institute biosafety level three (BSL-3) facility. Personal protective equipment and pathogen manipulation occurred as previously described recommended by the Biosafety in Microbiology or Biomedical Laboratories $(64,65)$.

Fungal Growth, Nucleic Acid Extraction and Sequencing: Fungal isolates were cultured as previously described $(65,66)$. Briefly, to confirm pure cultures the isolates were grown on $2 \mathrm{xGYE}\left(2 \%\right.$ glucose, $1 \%$ yeast extract agar) at $30^{\circ} \mathrm{C}$, for seven days. Next, small plugs of each isolates were used to inoculate liquid $2 \mathrm{xGYE}$ ( $2 \%$ glucose, $1 \%$ yeast extract) in vented baffled Erlenmeyer flasks and grown at $30^{\circ} \mathrm{C}$, for six days on a shaking incubator. These cultures were heat inactivated at $80^{\circ} \mathrm{C}$ for $30 \mathrm{~min}$ in fungal lysis buffer. Genomic DNA was obtain used traditional phenol:choloroform solvents and precipitated using isopropanol and EtOH. DNA quantity and quality was visualized on a $1 \%$ agarose gel. These samples were submitted for sequencing at the Translation Genomics Research Institute on a MiSeq V3 kit for 600 cycles. Raw reads have been deposited under accession number PRJNA722304.

Population Analysis: Raw reads for 60 previously published C. posadasii samples representing the Caribbean, Arizona, Texas/Mexico/South America clades (40) and the seven new clinical isolates were aligned to reference $C$. posadasii stain Silveira genome, accession number 
medRxiv preprint doi: https://doi.org/10.1101/2021.06.24.21258773; this version posted June 28, 2021. The copyright holder for this preprint (which was not certified by peer review) is the author/funder, who has granted medRxiv a license to display the preprint in perpetuity.

It is made available under a CC-BY-NC-ND 4.0 International license .

DNA mutations. The resulting SNP (Single Nucleotide Polymorphism) matrix was used to build a Maximum Likelihood tree using IQ-TREE version 1.6.1, based in 152,663 parsimony informative SNP's (68). The phylogenetic tree distribution was visualized using Figtree v1.4.4 (69).

4) Soil Collection, Nucleic Acid Extraction and Amplification: A total of 171 soil samples collected between 2018-2020 were included in this study (see Supplemental Table 2 for breakdown of samples and site descriptions). The sites in Northern Arizona drastically vary in ecosystem characteristics from each other as well as from habitat in the highly endemic Southern Arizona region for Valley Fever. Soils were collected and processed as previously described (49). Briefly, each sample was collected with a sterile garden trowel and stored in sterile $50 \mathrm{~mL}$ collection containers at room temperature until processing. DNA was extracted following kit recommendations using the Qiagen DNeasy Powersoil Pro Kit (Qiagen, Boston, MA, USA). The presence or absence of Coccidioides spp. DNA in soil samples was determined by two highly specific Taqman-based CocciCDX and CocciENV real-time qPCR assays using a Quant Studio 12k Flex Real-Time PCR System (ThermoFisher Scientific (70, 71). Each 20uL reaction contained 1 x Taqman Universal Master mix II (ThermoFisher Scientific), PRIMERS, with DNA template with the following thermocycling conditions: initial denaturation for $10 \mathrm{~min}$ at $95^{\circ} \mathrm{C}$ followed by 40 cycles of $15 \mathrm{~s}$ at $95^{\circ} \mathrm{C}$ and $1 \mathrm{~min}$ at $60^{\circ} \mathrm{C}$. Three technical replicates were run for each DNA sample. A reaction was considered positive if it showed logarithmic amplification, produced a CT value of $<40$.

\section{Results}

We sought to identify the number of recent diagnosed cases (2017-2019) of coccidioidomycosis in Northern Arizona compared to historical averages (2012-2016) and to compare the host 
medRxiv preprint doi: https://doi.org/10.1101/2021.06.24.21258773; this version posted June 28, 2021. The copyright holder for this preprint (which was not certified by peer review) is the author/funder, who has granted medRxiv a license to display the preprint in perpetuity.

It is made available under a CC-BY-NC-ND 4.0 International license .

208 specific factors of these cases to statewide trends. After which we focused on the in-patient

209 Valley fever patient population of Northern Arizona by performing a chart review during a

210 similar (18 month) time frame at the regional hospital. We then investigated the genetic structure

211 of fungal isolates collected and stored at the hospital compared to the recognized populations of

212 Coccidioides. Lastly, we searched for evidence of pathogen presence in Northern Arizona soils,

213 completing our epidemiologic triangle approach.

214 Diagnosed Valley fever cases are increasing in Northern Arizona counties

215 Northern Arizona counties are experiencing increased cases of Valley fever per 100,000

216 population compared to the historical trends defined by the health department (Figure 1). We

217 focused on 2017-18 as this time frame coincides with the hospital data available to us and chose

218 to also include 2019 data. In Mohave, Yavapai and Apache counties the number of cases per

219100,000 population doubled by 2019 in comparison to historical averages (Figure 1,

220 supplemental table 3). These findings are similar in counties across the state. The greatest

221 number of cases reported each year occur in Maricopa, Pima and Pinal counties which are

222 located in Southern Arizona (Figure 1). In general, all of the counties in Arizona are reporting an

223 increase in diagnosed cases each year and an increase in incidence per 100,000 population

224 (supplemental table 3 and 4) with a few exceptions. The age and sex of individuals testing

225 positive for Valley fever in northern counties are similar to statewide observations (supplemental

226 table 5). 


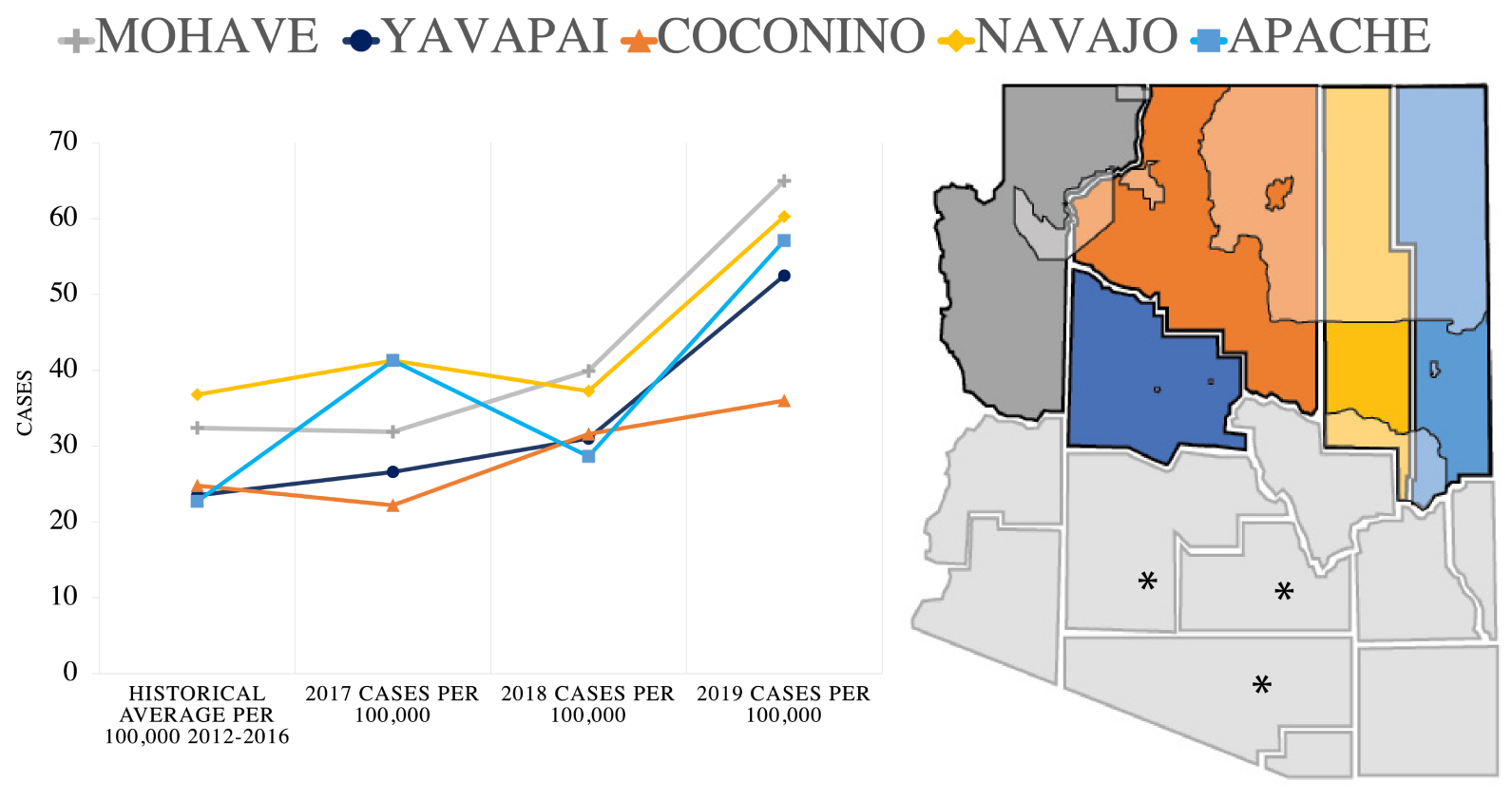

Figure 1. Northern Arizona county location and Valley fever cases. Yearly, the number of cases per 100,000 population are increasing compared to historical averages in all Northern Arizona counties. Geographic location of northern Arizona counties. Left to right, Mohave, Yavapai,

232 Coconino (largest), Navajo and Apache. Tribal land located in Northern Arizona counties are

233 shaded. The southern counties which experience the highest yearly case counts per 100,000 are denoted with asterisks.

Valley fever hospitalizations in Coconino county

237 Next, we surveyed all in-patient records at the regional hospital, Northern Arizona Healthcare

238 (NAH) for an 18-month period (7/13/2017-12/31/2018). The relatively short timeframe of this

239 retrospective review is a limitation of this study. Therefore, the previously mentioned county

240 case data was identified to complement the timeframe of this chart review. This regional medical center is located in Coconino county and often accepts patients from other Northern Arizona 
medRxiv preprint doi: https://doi.org/10.1101/2021.06.24.21258773; this version posted June 28, 2021. The copyright holder for this preprint (which was not certified by peer review) is the author/funder, who has granted medRxiv a license to display the preprint in perpetuity.

It is made available under a CC-BY-NC-ND 4.0 International license .

242

243

244

245

246

247

248

249

250

251

252

253

254

255

256

257

258

259

260

261

262

263

264

counties. During the time frame we investigated, there were 124 in-patients screened for Valley fever, 38 of them were positive for coccidioidomycosis (IgM 28, titer 16). Because statewide coccidioidomycosis hospitalization demographic data is not publicly available we compared these in-patient cases to all reported coccidioidomycosis case in Arizona in respect to sex and age (supplemental table 5, Figure 2A). In Arizona, reported cases of Valley fever is distributed approximately 50/50 among males and females with slight fluctuation each year (60). Of the 38 hospitalized patients there were 23 males $(60.5 \%)$ and 15 females $(39.5 \%)$. The greatest proportion of Arizona confirmed cases and in-patient cases occurred among individuals between 45-64 years of age. Among all 38 Valley fever hospital patients, we observed a range of comorbidities; diabetes $(16 \%)$, cancer $(10 \%)$, HIV (5\%) or in some cases multiple conditions (25\%). In total $23 \%$ of hospitalized patients did not have notable co-morbidities and were otherwise healthy (Figure $2 \mathrm{~B}$ ). For the 38 hospitalized cases, $82 \%$ of the fungal infections were restricted to pulmonary locations, and $18 \%$ experienced dissemination to other regions of the body (Figure 2C). Nationally, dissemination only occurs in between 1-5\% of reported Valley fever cases (25).

Next, we sought to compare racial demographics in NAH Valley fever cases with Arizona trends. Published literature suggests that individuals with African American or Filipino backgrounds are at increased risk for severe Valley fever $(26,72)$. Shockingly, in Arizona race/ethnicity is documented for only $\sim 29 \%$ of diagnosed cases (Table 1 ). This makes assessing especially vulnerable populations based on racial variation challenging and potentially inaccurate. At NAH, we were able to identify race/ethnicity in all cases (Table 1, Figure 2C). There were 14 white (36.8\%), 2 Hispanic (5.2\%) and 22 Native American/Alaskan Indian $(57.8 \%)$ cases. The observed proportion of diagnosed cases among individuals with Native 
medRxiv preprint doi: https://doi.org/10.1101/2021.06.24.21258773; this version posted June 28, 2021. The copyright holder for this preprint (which was not certified by peer review) is the author/funder, who has granted medRxiv a license to display the preprint in perpetuity.

It is made available under a CC-BY-NC-ND 4.0 International license .

American/Alaskan Indian heritage appears high (57.8\%) despite the population prevalence $(25.9 \%)$ in Coconino county and at NAH (35\%) compared to other ethnic groups (Table 1). This trend may be similar to findings released by the $\mathrm{CDC}$ which documented increased hospitalization in native American populations with Valley fever. However, statewide examining data when race is known, only $2.1 \%$ of the cases are observed in Native American/Alaskan Indian individuals, who make up $4.1 \%$ of the state's total population (Table 1).
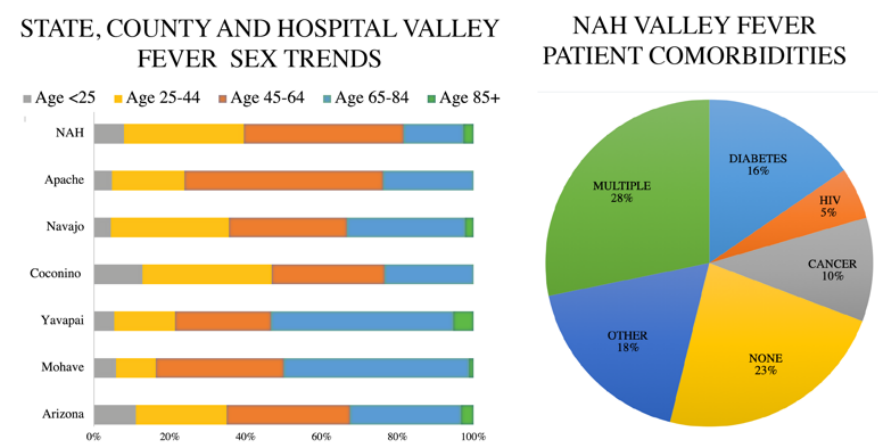

NAH TOTAL PATIENT POPULATION

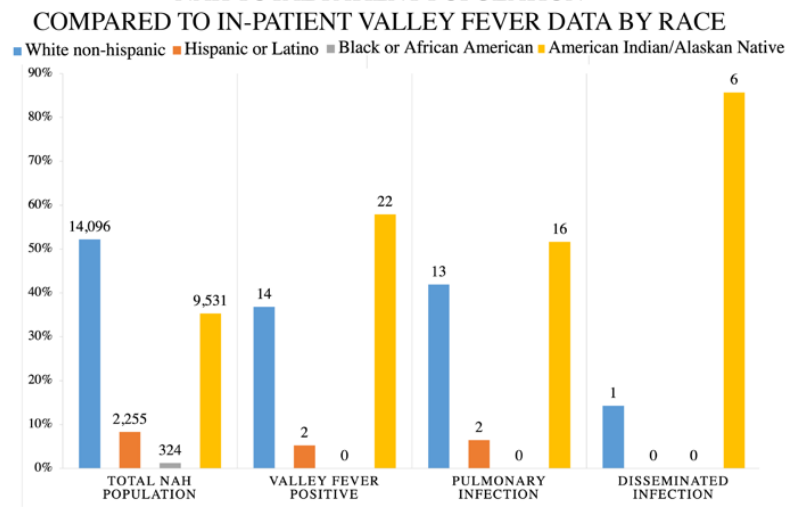

272 Figure 2. Northern Arizona Valley fever data demographics. 2A) Age of patients diagnosed with

273 Valley fever in Arizona during 2018, Northern Arizona counties during 2018, and regional

274 hospital (NAH) between (7/13/2017-12/31/2018). 2B) Among hospitalized Valley fever patients

275 at NAH $23 \%$ of patients had no documented pre-existing conditions. The other $77 \%$ had existing

276 co- morbidities such as diabetes (16\%), HIV (9\%), cancer (10\%), and is several cases multiple

277 immunocompromising conditions. 2C) The total population treated at NAH is displayed next to

278 in-patient Valley fever cases for reference. Out of the 38 patients diagnosed with Valley fever 
medRxiv preprint doi: https://doi.org/10.1101/2021.06.24.21258773; this version posted June 28, 2021. The copyright holder for this preprint (which was not certified by peer review) is the author/funder, who has granted medRxiv a license to display the preprint in perpetuity.

It is made available under a CC-BY-NC-ND 4.0 International license .

279 from (7/13/2017-12/31/2018) pulmonary infection occurred in $31(82 \%)$ cases, dissemination to

280 extrapulmonary locations occurred in $7(12 \%)$ of the cases. There were 14 white $(36.8 \%), 2$

281 Hispanic (5.2\%) and 22 Native American/Alaskan Indian (57.8\%) individuals.

282 Table 1. Breakdown of unknown and known race distribution for Valley fever cases in Arizona,

283 Coconino county and Northern Arizona Health Care.

\begin{tabular}{|c|c|c|c|c|c|c|}
\hline \multirow[t]{2}{*}{ Group } & \multicolumn{2}{|c|}{ Arizona $\%(n)$} & \multicolumn{2}{|c|}{ Coconino county $\%$ (n) } & \multicolumn{2}{|c|}{$\begin{array}{l}\text { Northern Arizona } \\
\text { Healthcare \% (n) }\end{array}$} \\
\hline & Population* & $\begin{array}{l}\text { Valley } \\
\text { fever** }\end{array}$ & Population* & $\begin{array}{l}\text { Valley } \\
\text { fever** }\end{array}$ & Population $* * *$ & $\begin{array}{l}\text { Valley } \\
\text { fever }\end{array}$ \\
\hline Unknown & $\mathrm{n} / \mathrm{a}$ & $\begin{array}{l}72.1 \% \\
(5,388)\end{array}$ & $\mathrm{n} / \mathrm{a}$ & 22 & $\begin{array}{l}1.5 \% \\
(399)\end{array}$ & 0 \\
\hline All groups & $7,278,717$ & 7,478 & 143,476 & 46 & 27,008 & 38 \\
\hline $\begin{array}{l}\text { White } \\
\text { non- } \\
\text { Hispanic }\end{array}$ & $\begin{array}{l}55.38 \% \\
(3,981,049)\end{array}$ & $\begin{array}{l}17.6 \% \\
(1,317)\end{array}$ & $\begin{array}{l}63.9 \% \\
(91,649)\end{array}$ & 14 & $\begin{array}{l}52.2 \% \\
(14,096)\end{array}$ & $\begin{array}{l}36.84 \% \\
(14)\end{array}$ \\
\hline $\begin{array}{l}\text { Hispanic } \\
\text { or Latino }\end{array}$ & $\begin{array}{l}31.7 \% \\
2,279,253\end{array}$ & $\begin{array}{l}4.3 \% \\
(325)\end{array}$ & $\begin{array}{l}14.27 \% \\
(21,023)\end{array}$ & & $\begin{array}{l}8.3 \% \\
(2,255)\end{array}$ & $\begin{array}{l}5.26 \% \\
(2)\end{array}$ \\
\hline $\begin{array}{l}\text { Black or } \\
\text { African } \\
\text { American }\end{array}$ & $\begin{array}{l}4.898 \% \\
352,121\end{array}$ & $\begin{array}{l}2.1 \% \\
(159)\end{array}$ & $\begin{array}{l}1.0 \% \\
(1,364)\end{array}$ & & $\begin{array}{l}1.2 \% \\
(324)\end{array}$ & 0 \\
\hline $\begin{array}{l}\text { American } \\
\text { Indian or }\end{array}$ & $\begin{array}{l}4.161 \% \\
299,123\end{array}$ & $\begin{array}{l}2.1 \% \\
(157)\end{array}$ & $\begin{array}{l}25.9 \% \\
(37,187)\end{array}$ & 10 & $\begin{array}{l}35.3 \% \\
(9,531)\end{array}$ & $\begin{array}{l}57.89 \% \\
(22)\end{array}$ \\
\hline
\end{tabular}




\begin{tabular}{|c|c|c|c|c|c|}
\hline $\begin{array}{l}\text { Alaska } \\
\text { Native }\end{array}$ & & & & & \\
\hline $\begin{array}{l}\text { Asian or } \\
\text { Pacific } \\
\text { Islander }\end{array}$ & $\begin{array}{l}3.86 \% \\
277,474\end{array}$ & $\begin{array}{l}1.1 \% \\
(84)\end{array}$ & $\begin{array}{l}2.2 \% \\
(3,149)\end{array}$ & $\begin{array}{l}0.8 \% \\
(225)\end{array}$ & 0 \\
\hline $\begin{array}{l}\text { Other/Two } \\
\text { or more }\end{array}$ & $\begin{array}{l}3.9 \% \\
280,574\end{array}$ & $\begin{array}{l}0.6 \% \\
(48)\end{array}$ & $\begin{array}{l}4.3 \% \\
(6,230)\end{array}$ & $\begin{array}{l}0.7 \% \\
(178)\end{array}$ & 0 \\
\hline
\end{tabular}

*ACS 2019 estimates census.gov

** Arizona Department of Health 2018 annual Valley fever report. Only 29\% of cases' ethnicity is known so data is unreliable.

*** Northern Arizona Healthcare, Flagstaff location 2017, 2018

Northern Arizona Clinical isolates originate from Arizona Coccidioides populations polymorphism) based matrix. A total of $82.72 \%$ or $23,336,819$ bases mapped to the reference

294 genome from which we detected 270,853 SNP's. Next, the IQTREE software was used to 295 identify the best nucleotide substitution model, TVM+F+ASC+R5 using 1,000 bootstrap 296 iterations to the distinguish the Maximum Likelihood tree. This analysis demonstrated that the 297 isolates obtained from patients at Northern Arizona Healthcare are genetically similar to either 298 isolates from Maricopa $(n=4)$ or Pima ( $n=3$ counties) and no unique genetic clusters were found 299 for the Northern Arizona samples. 


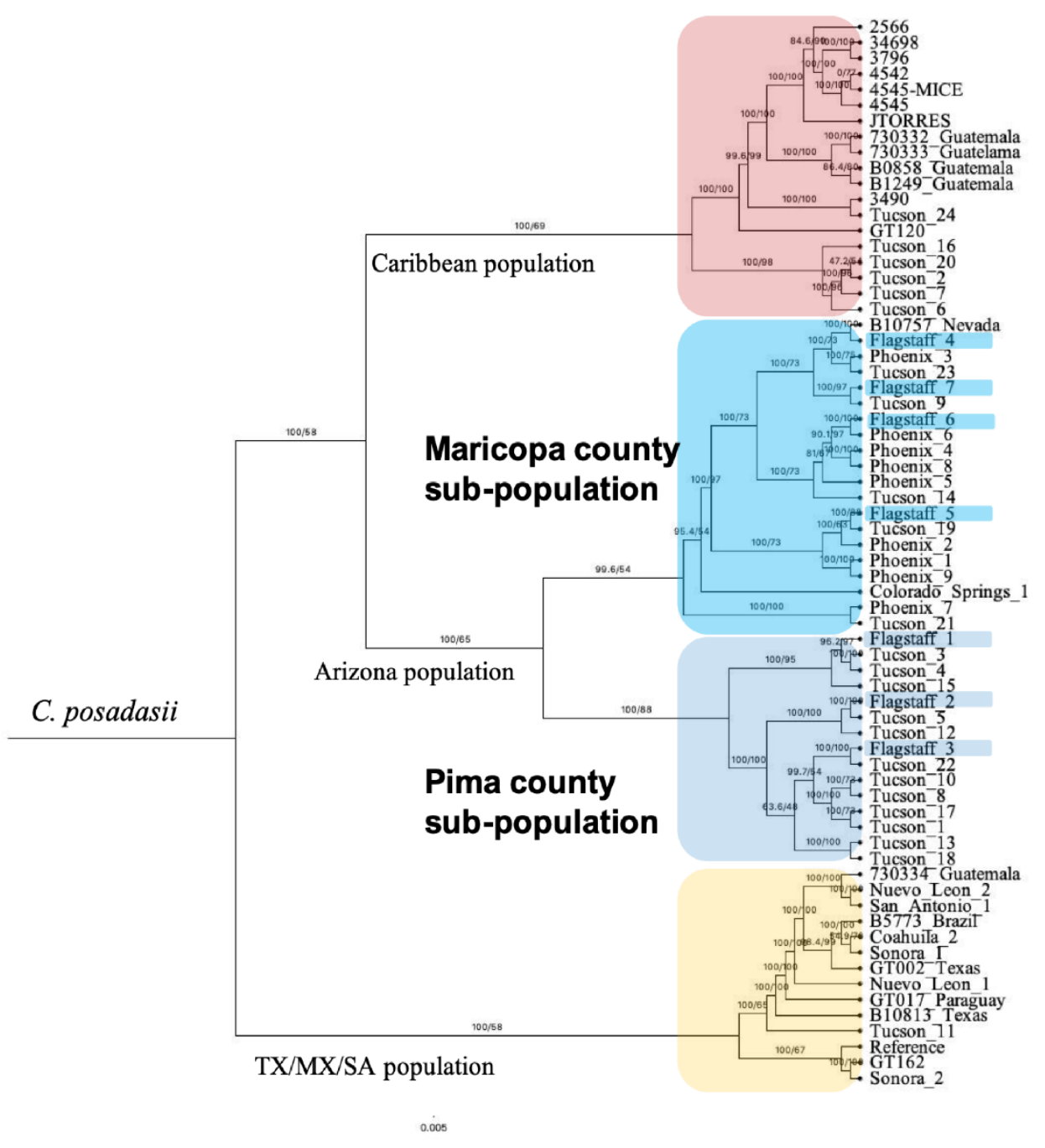

301 Figure 3. Relationship of Northern Arizona Clinical isolates within C. posadasii population suggests traveled related infection. The seven new clinical isolates (highlighted) group with previously published isolates recovered from patients in Maricopa or Pima county populations. C. posadasii is comprised of geographically distinct populations designated as Caribbean (top, red), Texas/Mexico and South America (bottom, yellow) and Arizona (middle, blues). Subpopulation structure in Arizona suggests genetically distinct groups with Arizona (Maricopa county; Phoenix and Pima county; Tucson). Mid-point Rooted Maximum Likelihood Tree built using 61 previously published and seven new isolates. 
medRxiv preprint doi: https://doi.org/10.1101/2021.06.24.21258773; this version posted June 28, 2021. The copyright holder for this preprint (which was not certified by peer review) is the author/funder, who has granted medRxiv a license to display the preprint in perpetuity.

It is made available under a CC-BY-NC-ND 4.0 International license.

We surveyed 171 soil samples obtained between 2018-2020 from Mohave, Yavapai,

311 Coconino, Navajo and Apache county for the evidence of Coccidioides DNA. We identified

312 positive samples in all of the counties, with varying rates of positivity (Figure 4 , Table 2 ). In

313 Mohave county there were 8/24 positive soil samples using both PCR assays (CDx and

314 CocciEnv). In Yavapai county there were 6/18 using CDx and 4/18 based on CocciENV results.

315 In Coconino county there were 6/75 positive CDx soils and none with CocciENV. Navajo county

316 had 2/32 CDx positive and none with CocciENV. Lastly, Apache county 2/22 soils which were

317 CDx positive and 3/22 CocciENV positive. In summary, 39 samples were positive for at least

318 one assay (Table 3). It is common to have varying results between the two PCR methods, both

319 which target Coccidioides specific alleles. Therefore, our results suggest that Coccidioides

320 species are present in Northern Arizona soil. If we consider samples positive for both PCR

321 methods, we identified six positive soils, which provides evidence that $C$. posadasii is present at

322 these sites.
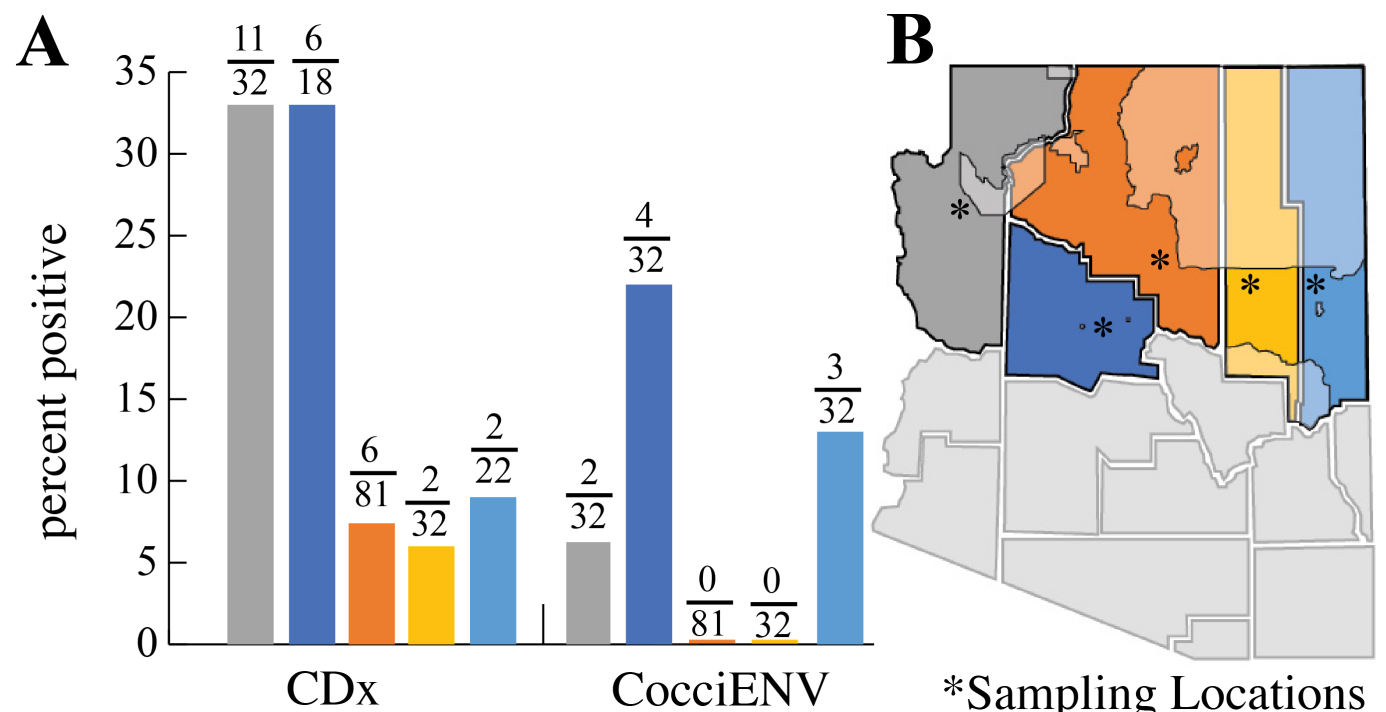
medRxiv preprint doi: https://doi.org/10.1101/2021.06.24.21258773; this version posted June 28, 2021. The copyright holder for this preprint (which was not certified by peer review) is the author/funder, who has granted medRxiv a license to display the preprint in perpetuity.

It is made available under a CC-BY-NC-ND 4.0 International license .

325 Figure 4. Northern Arizona soils are positive for Coccidioides DNA. 4A) Percent positivity for 326 soil in Mohave, Yavapai, Coconino, Navajo and Apache county. 4B) Approximate location of

327 soil collection sites designated with asterisk *. Tribal land located in Northern Arizona counties

328 are shaded.

329 Table 2. Evidence for Coccidioides in northern Arizona county soils.

\begin{tabular}{|c|c|c|c|c|c|c|c|}
\hline \multicolumn{8}{|c|}{ PCR results for CDX and CocciENV assays } \\
\hline \multirow[t]{2}{*}{ County } & \multirow{2}{*}{$\begin{array}{l}\text { Total } \\
\text { samples }\end{array}$} & \multicolumn{2}{|c|}{$\mathrm{CDx} \%(\mathrm{n})$} & \multicolumn{2}{|c|}{ CocciENV \% (n) } & \multicolumn{2}{|c|}{$\begin{array}{l}\text { CDx and CocciENV } \\
\text { assays }\end{array}$} \\
\hline & & Positive & Negative & Positive & Negative & Positive & Negative \\
\hline Mohave & 32 & $\begin{array}{l}33 \% \\
(11)\end{array}$ & $\begin{array}{l}66 \% \\
(21)\end{array}$ & $\begin{array}{l}6.25 \% \\
\text { (2) }\end{array}$ & $\begin{array}{l}93.75 \% \\
(30)\end{array}$ & 2 & 21 \\
\hline Yavapai & 18 & $\begin{array}{l}33 \% \\
(6)\end{array}$ & $\begin{array}{l}66 \% \\
(12)\end{array}$ & $\begin{array}{l}22 \% \\
(4)\end{array}$ & $\begin{array}{l}78 \% \\
(14)\end{array}$ & 3 & 11 \\
\hline Coconino & 81 & $\begin{array}{l}7.4 \% \\
(6)\end{array}$ & $\begin{array}{l}92.59 \% \\
(75)\end{array}$ & 0 & $\begin{array}{l}100 \% \\
(81)\end{array}$ & 0 & 75 \\
\hline Navajo & 32 & $\begin{array}{l}6 \% \\
(2)\end{array}$ & $\begin{array}{l}94 \% \\
(30)\end{array}$ & $\begin{array}{l}0 \% \\
(0)\end{array}$ & $\begin{array}{l}100 \% \\
(30)\end{array}$ & 0 & 30 \\
\hline Apache & 22 & $\begin{array}{l}9 \% \\
(2)\end{array}$ & $\begin{array}{l}91 \% \\
(20)\end{array}$ & $\begin{array}{l}13 \% \\
(3)\end{array}$ & $\begin{array}{l}87 \% \\
(20)\end{array}$ & 1 & 18 \\
\hline Total & 171 & 24 & 147 & 15 & 147 & 6 & 155 \\
\hline
\end{tabular}


medRxiv preprint doi: https://doi.org/10.1101/2021.06.24.21258773; this version posted June 28, 2021. The copyright holder for this preprint (which was not certified by peer review) is the author/funder, who has granted medRxiv a license to display the preprint in perpetuity.

It is made available under a CC-BY-NC-ND 4.0 International license .

Environmentally acquired diseases involve complex interactions between pathogen, host

and the environment. Each of these factors play a role in the outcome of infectious diseases. For Valley fever, individuals become exposed to fungal propagules that originate in arid desert soils. Alarmingly, the recognized soil habitat of Coccidioides spp. is actively expanding to regions as far north as Washington state and predicted to continue in response to climate variability $(55,57$, 58). In the southwestern United States where the desert environment supports fungal growth, exposure is likely inevitable for long term residents. This residential population is steadily increasing, often at a faster rate than the rest of the country combined, which results in an increase in naïve hosts (73). Indeed, these fungal infections are on the rise in the southwestern United States with most cases occurring in California and Arizona $(55,57,58,62)$. The number of reported cases in Arizona have been increasing, and here we focus on the northern counties of the state which are following this trend. In order to create a holistic view of coccidioidomycosis in Northern Arizona, we investigated the patterns of documented susceptible hosts, population structure of the local fungal isolates and the likelihood of the environment supporting the pathogens existence.

In Arizona it is mandatory to report confirmed cases of Valley fever, which allowed us to investigate current reported cases in comparison to historical trends. For each northern Arizona county, the number of total cases and cases per 100,000 population has trended up each year (supplemental tables 3 and 4). In Yavapai, Mohave and Apache counties, the number of cases per 100,000 doubled by 2019 in comparison to historical averages from 2012-2016 (Figure 1, supplemental table 3). Whether these infections are the result of travel to endemic regions of southern Arizona is unknown. Although the results of our soil survey suggest the pathogen may already be present in the region, travel between southern and northern Arizona is common and 
medRxiv preprint doi: https://doi.org/10.1101/2021.06.24.21258773; this version posted June 28, 2021. The copyright holder for this preprint (which was not certified by peer review) is the author/funder, who has granted medRxiv a license to display the preprint in perpetuity.

It is made available under a CC-BY-NC-ND 4.0 International license .

the more likely explanation (Table 2). We anticipated that regardless of the region of infection, host factors that lead to susceptibility would be similar. As suspected, individuals that test positive for coccidioidomycosis in northern Arizona counties share similar sex and age demographics as compared to state data (Figure 2A, supplemental table 5). Statewide, the ratio of male to females with a confirmed case of Valley fever is typically 50/50 with slight variation (48/52 in 2018) between each year (60). Individuals ages 45-64 are the most commonly diagnosed with Valley fever in Arizona, in the northern Arizona counties similar observations occurred. Because these observations are analogous in northern counties, physicians in the area should consider increased screening for Valley fever, especially among individuals age 45-64 who display symptoms of respiratory infection.

In this study, we demonstrate that thirty-eight cases of Valley fever were treated at the regional medical center during an 18-month period. We set out to compare these northern Arizona in-patients to the greater Arizona statewide Valley fever populations to determine if any other factors were contributing to disease and again found similar trends in regard to age and sex (Table 1, Figure 2). Racial category is a crucial but often missing factor we identified during our study. In total, $57.8 \%(22 / 38)$ of the patients identified as AI/AN (Table 2). Sixty percent is a value higher than expected given that NAH's typical patient population is 35\% AI/AN (Table 1). We acknowledge that many socioeconomic factors such as access to healthy food, income level and quality healthcare can play a role in disease response (74-76). Untangling the complexity of racism and health disparities is a long-standing challenge in epidemiology studies (77). Importantly, overwhelming evidence suggest race as it relates to disease susceptibility is a proxy for a number of underlying factors and that socioeconomic status (SES) rather than racial variation influences health outcomes $(29,77,78)$. Nevertheless, in Arizona, over $70 \%$ of 
medRxiv preprint doi: https://doi.org/10.1101/2021.06.24.21258773; this version posted June 28, 2021. The copyright holder for this preprint (which was not certified by peer review) is the author/funder, who has granted medRxiv a license to display the preprint in perpetuity.

It is made available under a CC-BY-NC-ND 4.0 International license .

378 documented statewide cases do not include race/ethnicity in the disease report. Therefore,

379 identifying an expected distribution of Valley fever cases across racial categories is inaccurate

380 with currently available data (Table 2) (60). The racial diversity in northern Arizona is quite

381 different than the southern parts of the state, specifically in regard to Native populations $(79,80)$.

382 In total American Indian/Alaskan Natives (AI/AN) make up only 4\% of the Arizona population.

383 In contrast, large areas of tribal land exist in Coconino, Navajo and Apache counties hence the

384 percent of tribal members are higher than any other counties in the state (Figure 1 and 2).

385 Therefore, compared to other races and the total population in each county the percentage of

$\mathrm{AI} / \mathrm{AN}$ individuals documented in Coconino county is $26 \%$, in Navajo county is $44 \%$ and Apache county is $73 \%$. In contrast, tribal area is smaller in Mohave and Yavapai counties, and therefore the percent of $\mathrm{AI} / \mathrm{AN}$ in respect to the total populations is $2.2 \%$ and $1.6 \%$ respectively (supplemental table 6). Research on the susceptibility of native populations to develop severe Valley fever has always suggested concern. In 1974, it was reported that southwestern tribal members had three to five times higher morbidity and mortality rates, compared to whites

392 located in or near the same region, in response to Valley fever (81). A follow up paper in 1985

393 focused on a decreased dissemination in southern tribes (from 8.9-3.9\%) however, elevated mortality rates of native patients compared to that of white populations in the same region still

395 remained (82). More recently, a substantial proportion of Valley fever samples collected in New

396 Mexico were derived from Native American patients (59). At a similar time, the Center for

397 Disease Control (CDC) identified that native populations suffered the highest rate of 398 coccidioidomycosis associated hospitalization out of any other race nationwide (27). The discussion emphasized that increased dissemination and mortality rates of coccidioidomycosis in 
medRxiv preprint doi: https://doi.org/10.1101/2021.06.24.21258773; this version posted June 28, 2021. The copyright holder for this preprint (which was not certified by peer review) is the author/funder, who has granted medRxiv a license to display the preprint in perpetuity.

It is made available under a CC-BY-NC-ND 4.0 International license .

400

401

402

403

404

405

406

407

408

409

410

411

412

413

414

415

416

417

418

419

420

421

422

part were due to delayed diagnosis, which further supports that access to quality healthcare or other SES factors influence disease outcomes $(27,74,77,83)$.

Delays in diagnosis are particularly problematic in symptomatic Valley fever cases.

Rapid and accurate diagnosis allows clinicians to monitor disease progression, and determine the appropriate intervention strategies. In contrast, severe disease or dissemination can occur when symptomatic disease is left untreated (25). Our chart review suggests that many of the NAH patients had co-morbidities such as HIV, cancer, or diabetes, which are known to increase disease susceptibility. However, $23 \%$ of the patients did not have any immune suppression conditions other than Valley fever, reminding us that this disease can be damaging to otherwise healthy individuals. Of the hospitalized patients $19 \%$ had fungal infections disseminate beyond the respiratory system. These data on dissemination are beyond the $1-5 \%$ estimate that is expected for Valley fever $(25,32)$. Interestingly, six or $85 \%$ of these disseminated cases identified as AI/AN. This again suggests that tribal members may be at increased risk for dissemination compared to other races, as proposed previously $(27,81)$. Of note, the CDC report did suggest that the high level of coccidioidomycosis could be due the high proportion of individuals that live in the endemic region (southwestern US). Our study is focused on northern Arizona which includes a large proportion of tribal land (which extends into CO, NM and UT). While this area is in/near the endemic zone, it is not an area traditionally considered to be high risk for acquiring the disease (Figure 1 and 2). The risk may be higher than originally thought based on the increasing county Valley fever case counts per 100,000 population and hospitalizations reported in northern Arizona. Previously, health disparities for AI/AN have been documented for other diseases $(83,84)$. If NAH is treating a higher proportion of AI/AN with Valley fever than expected, these findings are consistent with calculations performed by the 
medRxiv preprint doi: https://doi.org/10.1101/2021.06.24.21258773; this version posted June 28, 2021. The copyright holder for this preprint (which was not certified by peer review) is the author/funder, who has granted medRxiv a license to display the preprint in perpetuity.

It is made available under a CC-BY-NC-ND 4.0 International license .

423 CDC and follow up studies should be designed to address this observation, while considering

424 race and SES factors $(27,78)$. Whether the risk is due to racism, discrimination, socioeconomic

425 variables, genetic factors, and/or the presence of environmental pathogens, it should be more

426 formally investigated. Our report indicates that a general increased awareness among hospitals,

427 physicians and local populations in Northern Arizona is needed to quickly identify and treat

428 Coccidioides infections.

429

Working with Coccidioides spp. requires biosafety level 3 (BSL-3) containment and

430 therefore culturing is not the primary method of diagnosis for most clinical laboratories, limiting

431 the availability of clinical isolates. The seven isolates obtained at NAH represent a unique

432 opportunity to investigate the pathogen component of infections in the region. The Coccidioides

433 genus is comprised of two genetically distinct species, each with geographically defined

434 subpopulations $(38,40)$. C. immitis found in California and Washington and C. posadasii found

435 in Arizona, Texas, Mexico and Latin America (38, 40-42, 54, 55). Interestingly, a recent

436 publication documented Coccidioides isolates from New Mexico patients represent both $C$.

437 immitis and C. posadasii infections, it is likely that C. immitis infections are travel related (59).

438 Because geographic origin of the fungus can be determined by genetics, we compared the NAH

439 isolates to previously published data sets (40-42). We identified that the newly obtained clinical

440 isolates from Coconino county are C. posadasii with genetic proximity to other Arizona isolates

441 that originate from southern AZ counties such as Maricopa and Pima. In contrast, the new

442 clinical isolates do not group with Tex/Mex/SA or Caribbean C. posadasii populations. While at

443 the time of sample collection the patients in our study resided in northern Arizona counties,

444 travel/previous residency information was sparse. One patient reported previously living in

445 California and another traveled to northern Mexico, but dates were not provided. These findings 
medRxiv preprint doi: https://doi.org/10.1101/2021.06.24.21258773; this version posted June 28, 2021. The copyright holder for this preprint (which was not certified by peer review) is the author/funder, who has granted medRxiv a license to display the preprint in perpetuity.

It is made available under a CC-BY-NC-ND 4.0 International license .

446

447

448

449

450

451

452

453

454

455

456

457

458

459

460

461

462

463

464

465

466 467 unknown.

468

\section{Summary}

demonstrate that these particular NAH patients were infected with isolates from the different Arizona genotypes rather than a unique genetic variant in northern Arizona.

Northern Arizona's environment is not generally considered preferred habitat for

Coccidioides. This has been assumed based on the lower number of cases in the area, which, when they are diagnosed, are attributed to travel or previous residency in highly endemic southern regions of the state. Here we provide evidence of Coccidioides posadasii DNA in the soil in all of the northern Arizona counties we tested. Interestingly, both CDx and CocciENV assays target alleles that are unique to the genus $(91,96)$ respectively. Our results demonstrate the presence of Coccidioides DNA in a wide range of northern Arizona locations, six of which were positive using both assays, and thus we would expect that cases would be higher across the region. A reasonable explanation would be the presence of a less virulent or novel species in the region, which may not cause severe disease in humans but still be captured by the molecular assays. Reduction in virulence due to evolutionary tradeoff adaptations relate to temperature, precipitation, competition and biodiversity as observed in other species $(85,86)$. Alternatively, wind dispersed Coccidioides arthroconidia from southern endemic regions may deposit conidia, but these have only recently established in response to climate variability as predicted (58). This could be an alternate explanation for the local clinical isolates grouping with southern Arizona populations. The ability of arthroconidia to travel this distance and successfully propagate is unknown and difficult to model. Models predict an expansion of suitable habitat, which includes Northern Arizona, will soon be hospitable to Coccidioides in response to climate change. How this will impact already present novel species or wind dispersed disease causing strains is 
medRxiv preprint doi: https://doi.org/10.1101/2021.06.24.21258773; this version posted June 28, 2021. The copyright holder for this preprint (which was not certified by peer review) is the author/funder, who has granted medRxiv a license to display the preprint in perpetuity.

It is made available under a CC-BY-NC-ND 4.0 International license .

Here in we discuss the complex interactions between the environmentally associated fungal pathogen Coccidioides, which among susceptible human populations is causing the

471 disease coccidioidomycosis in northern Arizona. Our work suggests that the incidence of

472 diagnosed cases is rising in counties located in northern Arizona, some of which are severe

473 enough to require hospitalization. Individuals with confirmed cases demonstrated similar

474 demographics as the rest of the state in regard to sex and age. We observed that $57 \%$ of

475 hospitalized patients were of AI/AN heritage, however we are unable to determine if this

476 represents an increase risk without reliable statewide data on race/ethnicity of cases. Increased

477 reporting of patient race statewide is needed to identify disease trends specific to demographics

478 represented in the southwest. Lastly, we identified that the available clinical isolates from the

479 hospital are genetically related to Southern Arizona C. posadasii isolates and do not originate

480 from other populations found in Texas, Mexico or California. Our soil survey data suggests that

481 the pathogen is detectable in Northern Arizona soils, which has never previously been

482 recognized. This indicates the region supports the existence of Coccidioides species in the

483 environment. Collectively, our work describes the Valley fever disease triangle which considers

484 the interplay between host, pathogen and environment in Northern Arizona. Until disease

485 prevention is a feasible option, we anticipate that incidence of Valley fever will increase in the

486 area. Therefore, enhanced awareness and screening for the disease is vital to the communities of

487 Northern Arizona.

488 Study Limitations

To our knowledge this study is the first attempt to consider the interaction of host,

490 pathogen and environment which contribute to Valley fever in northern Arizona. Therefore, results and discussion presented here are an estimate, with need for further data collection. Our 
medRxiv preprint doi: https://doi.org/10.1101/2021.06.24.21258773; this version posted June 28, 2021. The copyright holder for this preprint (which was not certified by peer review) is the author/funder, who has granted medRxiv a license to display the preprint in perpetuity.

It is made available under a CC-BY-NC-ND 4.0 International license .

492

493

494

495

496

497

498

499

500

501

502

503

504

505

506

507

508

509

510

511

512

513 514 Terriquez.

goal was to document Valley fever trends in northern Arizona with data at hand. We present Valley fever cases and cases per 100,000 to account for reported cases and population fluctuation. However, we acknowledge that the number of Valley fever tests administered (positive and negative) can impact these numbers. We did not have access to these data, and thus this is a limitation of our interpretation. Additionally, individuals with Valley fever must seek medical care and be tested to be included in the reported case counts. Subsequently, our county data and in-patient hospital data do not reflect asymptomatic cases, individuals without access to medical care or misdiagnosis. Ideally, the retrospective chart review would encompass a longer time span, however due to the current pandemic we chose to present the current data rather than request further hospital resources. As previously mentioned, culturing is not the primary determinate for Valley fever diagnosis, therefore we had limited access to clinical isolates. While we were able to determine the genetic relationship of these isolates described above, we cannot make inferences about the genetic or geographic relationship of infections where clinical isolates were not collected. Lastly, the PCR methods utilized in this study detect Coccidioides DNA, which does not confirm the presence of live infectious organisms, but rather suggests it.

Acknowledgments Appreciation to note.louis designs for map/figure creation (fig1,fig 4).

Funding B.M.B received funding for soil collection and analysis under ABRC 16-162415.

Sequencing funds were awarded to H.L.M by The Center for Ecosystem Science and Society (Ecoss) and the McAllister Program in Community, Culture and Environment at Northern Arizona University. Isolates were collected under IBR No. 764034 through Northern Arizona Healthcare as part of the Northern Arizona University Biobank. Funding for this biobank was provided by the Flinn Foundation of Arizona seed grant \#1978 to P. Keim and J. 
medRxiv preprint doi: https://doi.org/10.1101/2021.06.24.21258773; this version posted June 28, 2021. The copyright holder for this preprint (which was not certified by peer review) is the author/funder, who has granted medRxiv a license to display the preprint in perpetuity.

\section{References}

1. Scholthof KB. The disease triangle: pathogens, the environment and society. Nat Rev Microbiol. 2007 Feb;5(2):152-6.

2. Burdon JJ, Zhan J. Climate change and disease in plant communities. PLoS Biol. 2020 Nov;18(11):e3000949.

3. Fisher MC, Henk DA, Briggs CJ, Brownstein JS, Madoff LC, McCraw SL, et al. Emerging fungal threats to animal, plant and ecosystem health. Nature. 2012 Apr 11;484(7393):186-94.

4. CDC. Novel Coronavirus (2019-nCoV) Wuhan, China. 2019 [cited February 14, 2021]; Available from: https://www.cdc.gov/coronavirus/2019ncov/index.html?CDC_AA_refVal=https $\% 3 \mathrm{~A} \% 2 \mathrm{~F} \% 2 \mathrm{Fwww} . \mathrm{cdc}$. gov $\% 2 \mathrm{Fcoronavirus} \% 2 \mathrm{Fnovel}-$ coronavirus-2019.html

5. Menachery VD, Yount BL, Jr., Debbink K, Agnihothram S, Gralinski LE, Plante JA, et al. A SARS-like cluster of circulating bat coronaviruses shows potential for human emergence. Nat Med. 2015 Dec;21(12):1508-13.

6. Rehman SU, Shafique L, Ihsan A, Liu Q. Evolutionary Trajectory for the Emergence of Novel Coronavirus SARS-CoV-2. Pathogens. 2020 Mar 23;9(3).

7. Centers for Disease C, Prevention. Increase in reported coccidioidomycosis--United States, 1998-2011. MMWR Morb Mortal Wkly Rep. 2013 Mar 29;62(12):217-21.

8. Freedman MB AS, Benedict K, McCotter O, Derado G, Hoekstra R, et al. Preliminary estimates of annual burden of coccidioidomycosis in the United States, 2010-2014. In: Group CS, editor. Coccidioidomycosis Study Group 61st Annual Meeting in collaboration with the 7th International Coccidioidomycosis Symposium. Palo Alto CA. Standford CA: Coccidioidomycosis Study Group; 2017. p. 32.

9. McCotter OZ, Benedict K, Engelthaler DM, Komatsu K, Lucas KD, Mohle-Boetani JC, et al. Update on the Epidemiology of coccidioidomycosis in the United States. Med Mycol. 2019 Feb 1;57(Supplement_1):S30-S40.

10. Galgiani JN, Ampel NM, Catanzaro A, Johnson RH, Stevens DA, Williams PL. Practice guidelines for the treatment of coccidioidomycosis. Clin Infect Dis. 2000 Apr;30(4):658-61.

11. Thompson GR, 3rd. Pulmonary coccidioidomycosis. Semin Respir Crit Care Med. 2011 Dec;32(6):754-63.

12. Chiller T. Overview of Endemic Mycoses. Vaccine Strategies for Endemic Fungal Pathogens; 2019 2019; Rockville, Maryland; 2019.

13. Chi GC, Benedict K, Beer KD, Jackson BR, McCotter O, Xie F, et al. Antibiotic and antifungal treatment among persons with confirmed coccidioidomycosis - Southern California, 2011. Med Mycol. 2020 Apr 1;58(3):411-3.

14. Jones JM, Koski L, Khan M, Brady S, Sunenshine R, Komatsu KK. Coccidioidomycosis: An underreported cause of death-Arizona, 2008-2013. Med Mycol. 2018 Feb 1;56(2):172-9.

15. Valdivia L, Nix D, Wright M, Lindberg E, Fagan T, Lieberman D, et al. Coccidioidomycosis as a common cause of community-acquired pneumonia. Emerging Infectious Diseases. 2006 Jun;12(6):958-62.

16. Kim MM, Blair JE, Carey EJ, Wu Q, Smilack JD. Coccidioidal pneumonia, Phoenix, Arizona, USA, 2000-2004. Emerg Infect Dis. 2009 Mar;15(3):397-401.

17. Chang DC, Anderson S, Wannemuehler K, Engelthaler DM, Erhart L, Sunenshine RH, et al. Testing for coccidioidomycosis among patients with community-acquired pneumonia. Emerg Infect Dis. 2008 Jul;14(7):1053-9. 
18. Chow NA, Griffin DW, Barker BM, Loparev VN, Litvintseva AP. Molecular detection of airborne Coccidioides in Tucson, Arizona. Med Mycol. 2016 Aug 1;54(6):584-92.

19. Gade L, McCotter OZ, Bowers JR, Waddell V, Brady S, Carvajal JA, et al. The detection of Coccidioides from ambient air in Phoenix, Arizona: Evidence of uneven distribution and seasonality. Med Mycol. 2020 Jun 1;58(4):552-9.

20. Kirkland TN, Fierer J. Coccidioides immitis and posadasii; A review of their biology, genomics, pathogenesis, and host immunity. Virulence; 2018. p. 1426-35.

21. Cole GT, Hurtgen BJ, Hung CY. Progress Toward a Human Vaccine Against Coccidioidomycosis. Curr Fungal Infect Rep. 2012 Dec 1;6(4):235-44.

22. Castro-Lopez N, Hung CY. Immune Response to Coccidioidomycosis and the Development of a Vaccine. Microorganisms. 2017 Mar 16;5(1).

23. Luo R, Greenberg A, Stone CD. Hospitalized burden and outcomes of coccidioidomycosis: A nationwide analysis, 2005-2012. Med Mycol. 2017 Jun 1;55(4):368-74.

24. Masannat FY, Ampel NM. Coccidioidomycosis in patients with HIV-1 infection in the era of potent antiretroviral therapy. Clin Infect Dis. 2010 Jan 1;50(1):1-7.

25. Odio CD, Marciano BE, Galgiani JN, Holland SM. Risk Factors for Disseminated Coccidioidomycosis, United States. Emerg Infect Dis. 2017 Feb;23(2).

26. Ruddy BE, Mayer AP, Ko MG, Labonte HR, Borovansky JA, Boroff ES, et al. Coccidioidomycosis in African Americans. Mayo Clin Proc. 2011 Jan;86(1):63-9.

27. McCotter O, Kennedy J, McCollum J, Bartholomew M, Iralu J, Jackson BR, et al. Coccidioidomycosis Among American Indians and Alaska Natives, 2001-2014. Open Forum Infect Dis. 2019 Mar;6(3):ofz052.

28. Galgiani JN. How does genetics influence Valley Fever? Research underway now to answer this question. AZ Medicine. 2014;Fall:30-3.

29. El-Sayed AM. Complex systems for a complex issue: race in health research. Virtual Mentor. 2014 Jun 1;16(6):450-4.

30. Lewis ER, David VR, Doyle AL, Rajabi K, Kiefer JA, Pirrotte P, et al. Differences in Host Innate Responses among Coccidioides Isolates in a Murine Model of Pulmonary Coccidioidomycosis. Eukaryot Cell. 2015 Oct;14(10):1043-53.

31. Louie L, Ng S, Hajjeh R, Johnson R, Vugia D, Werner SB, et al. Influence of host genetics on the severity of coccidioidomycosis. Emerg Infect Dis. 1999 Sep-Oct;5(5):672-80.

32. Nguyen C, Barker BM, Hoover S, Nix DE, Ampel NM, Frelinger JA, et al. Recent advances in our understanding of the environmental, epidemiological, immunological, and clinical dimensions of coccidioidomycosis. Clin Microbiol Rev. 2013 Jul;26(3):505-25.

33. Van Dyke MCC, Teixeira MM, Barker BM. Fantastic yeasts and where to find them: the hidden diversity of dimorphic fungal pathogens. Curr Opin Microbiol. 2019 Jun 7;52:55-63.

34. Drutz DJ, Huppert M. Coccidioidomycosis: factors affecting the host-parasite interaction. J Infect Dis. 1983 Mar;147(3):372-90.

35. Cole G.T. SSH. Arthroconidium-Spherule-Endospore Transformation in Coccidioides immitis. In: Szaniszlo P.J., Harris J.L. (eds) Fungal Dimorphism. Springer, Boston, MA.; 1985. p. 281-333.

36. Sil A, Andrianopoulos A. Thermally Dimorphic Human Fungal Pathogens--Polyphyletic Pathogens with a Convergent Pathogenicity Trait. Cold Spring Harb Perspect Med. 2014 Nov 10;5(8):a019794. 
medRxiv preprint doi: https://doi.org/10.1101/2021.06.24.21258773; this version posted June 28, 2021. The copyright holder for this preprint (which was not certified by peer review) is the author/funder, who has granted medRxiv a license to display the preprint in perpetuity. It is made available under a CC-BY-NC-ND 4.0 International license .

37. Sharpton TJ, Stajich JE, Rounsley SD, Gardner MJ, Wortman JR, Jordar VS, et al. Comparative genomic analyses of the human fungal pathogens Coccidioides and their relatives. Genome Res. 2009 Oct;19(10):1722-31.

38. Fisher MC, Koenig GL, White TJ, Taylor JW. Molecular and phenotypic description of Coccidioides posadasii sp. nov., previously recognized as the non-California population of Coccidioides immitis. Mycologia. 2002 Jan-Feb;94(1):73-84.

39. Barker BM, Tabor JA, Shubitz LF, Perrill R, Orbach MJ. Detection and phylogenetic analysis of Coccidioides posadasii in Arizona soil samples. Fungal Ecol. 2012;5(2):163-76.

40. Engelthaler DM, Roe CC, Hepp CM, Teixeira M, Driebe EM, Schupp JM, et al. Local Population Structure and Patterns of Western Hemisphere Dispersal for Coccidioides spp., the Fungal Cause of Valley Fever. MBio. 2016 Apr 26;7(2):e00550-16.

41. Teixeira MM, Alvarado P, Roe CC, Thompson GR, 3rd, Patane JSL, Sahl JW, et al. Population Structure and Genetic Diversity among Isolates of Coccidioides posadasii in Venezuela and Surrounding Regions. mBio. 2019 Nov 26;10(6).

42. Teixeira MM, Barker BM. Use of Population Genetics to Assess the Ecology, Evolution, and Population Structure of Coccidioides. Emerg Infect Dis. 2016 Jun;22(6):1022-30.

43. Berman RJ, Friedman L, Roessler WG, Smith CE. The virulence and infectivity of twentyseven strains of Coccidioides immitis. Am J Hyg. 1956 Sep;64(2):198-210.

44. Friedman L, Smith CE, Gordon LE. The assay of virulence of Coccidioides in white mice. J Infec Dis. 1955 Nov-Dec;97(3):311-6.

45. Cox RA, Magee DM. Coccidioidomycosis: host response and vaccine development. Clin Microbiol Rev. 2004 Oct;17(4):804-39, table of contents.

46. Shubitz LF, Powell DA, Butkiewicz CD, Lewis ML, Trinh HT, Frelinger JA, et al. A Chronic Murine Disease Model of Coccidioidomycosis Using Coccidioides posadasii, strain 1038. 2020 in press.

47. Shubitz LF PD, Butkiewicz CD, Lewis ML, Trinh HT, Frelinger JA, Orbach MJ, Galgiani JN,. A Chronic Murine Disease Model of Coccidioidomycosis Using Coccidioides posadasii, strain 1038. Journal Infectios Disease; 2020.

48. Taylor JW, Barker BM. The endozoan, small-mammal reservoir hypothesis and the life cycle of Coccidioides species. Med Mycol. 2019 Feb 1;57(Supplement_1):S16-S20.

49. Kollath DR, Teixeira MM, Funke A, Miller KJ, Barker BM. Investigating the Role of Animal Burrows on the Ecology and Distribution of Coccidioides spp. in Arizona Soils. Mycopathologia. 2020 Feb;185(1):145-59.

50. Alvarado P, Teixeira MM, Andrews L, Fernandez A, Santander G, Doyle A, et al. Detection of Coccidioides posadasii from xerophytic environments in Venezuela reveals risk of naturally acquired coccidioidomycosis infections. Emerg Microbes Infect. 2018 Mar 29;7(1):46. 51. Baptista-Rosas RC C-DJ, Romero-Olivares AL, Hinojosa A, Cavazos T, Riquelme M. Molecular detection of Coccidioides spp. from environmental samples in Baja California: linking Valley Fever to soil and climate conditions. Fungal Ecol.; 2012. p. 177-90.

52. Johnson SM, Carlson EL, Fisher FS, Pappagianis D. Demonstration of Coccidioides immitis and Coccidioides posadasii DNA in soil samples collected from Dinosaur National Monument, Utah. Med Mycol. 2014 Aug;52(6):610-7.

53. Eulalio KD, de Macedo RL, Cavalcanti MA, Martins LM, Lazera MS, Wanke B. Coccidioides immitis isolated from armadillos (Dasypus novemcinctus) in the state of Piaui, northeast Brazil. Mycopathologia. 2001;149(2):57-61. 
medRxiv preprint doi: https://doi.org/10.1101/2021.06.24.21258773; this version posted June 28, 2021. The copyright holder for this preprint (which was not certified by peer review) is the author/funder, who has granted medRxiv a license to display the preprint in perpetuity. It is made available under a CC-BY-NC-ND 4.0 International license .

54. Fisher MC, Koenig GL, White TJ, San-Blas G, Negroni R, Alvarez IG, et al. Biogeographic range expansion into South America by Coccidioides immitis mirrors New World patterns of human migration. Proc Natl Acad Sci U S A. 2001 Apr 10;98(8):4558-62.

55. Litvintseva AP, Marsden-Haug N, Hurst S, Hill H, Gade L, Driebe EM, et al. Valley fever: finding new places for an old disease: Coccidioides immitis found in Washington State soil associated with recent human infection. Clinical infectious diseases : an official publication of the Infectious Diseases Society of America. 2015 Jan 1;60(1):e1-3.

56. Marsden-Haug N, Goldoft M, Ralston C, Limaye AP, Chua J, Hill H, et al. Coccidioidomycosis acquired in Washington State. Clin Infect Dis. 2013 Mar;56(6):847-50.

57. Gorris ME, Cat LA, Zender CS, Treseder KK, Randerson JT. Coccidioidomycosis Dynamics in Relation to Climate in the Southwestern United States. Geohealth. 2018 Jan;2(1):624.

58. Gorris ME, Treseder KK, Zender CS, Randerson JT. Expansion of Coccidioidomycosis Endemic Regions in the United States in Response to Climate Change. Geohealth. 2019 Oct;3(10):308-27.

59. Hamm PS, Hutchison MI, Leonard P, Melman S, Natvig DO. First Analysis of Human Coccidioides Isolates from New Mexico and the Southwest Four Corners Region: Implications for the Distributions of C. posadasii and C. immitis and Human Groups at Risk. Journal of fungi (Basel). 2019 Aug 10;5(3).

60. AZDHS. Valley Fever Data, Reports \& Publications. [cited; Available from: https://www.azdhs.gov/preparedness/epidemiology-disease-control/valley-

fever/index.php\#reports-publications

61. !!! INVALID CITATION !!! (8).

62. Bezold CP, Khan MA, Adame G, Brady S, Sunenshine R, Komatsu K. Notes from the Field: Increase in Coccidioidomycosis - Arizona, October 2017-March 2018. MMWR Morb Mortal Wkly Rep. 2018 Nov 9;67(44):1246-7.

63. Services ADoH. Valley fever Data, Reports \& Publications . online: Arizona Department of Health Services.

64. Biosafety in Microbiological and Biomedical Laboratories (BMBL) 5th Edition.

65. Mead HL, Blackmon VA, Vogler JA, Barker MB. Heat Inactivation of Coccidioides posadasii and Coccidioides immitis for Use in Lower Biosafety Containment. Applied Biosafety. 2019 2019-06-16.

66. Mead HL, Van Dyke MCC, Barker BM. Proper Care and Feeding of Coccidioides: A Laboratorian's Guide to Cultivating the Dimorphic Stages of C. immitis and C. posadasii. Curr Protoc Microbiol. 2020 Sep;58(1):e113.

67. Sahl JW, Lemmer D, Travis J, Schupp JM, Gillece JD, Aziz M, et al. NASP: an accurate, rapid method for the identification of SNPs in WGS datasets that supports flexible input and output formats. Microb Genom. 2016 Aug;2(8):e000074.

68. Nguyen LT, Schmidt HA, von Haeseler A, Minh BQ. IQ-TREE: a fast and effective stochastic algorithm for estimating maximum-likelihood phylogenies. Mol Biol Evol. 2015 Jan;32(1):268-74.

69. Rambaut A. FigTree v1.4.4. p. FigTree is designed as a graphical viewer of phylogenetic trees and as a program for producing publication-ready figures.

70. Bowers JR, Parise KL, Kelley EJ, Lemmer D, Schupp JM, Driebe EM, et al. Direct detection of Coccidioides from Arizona soils using CocciENV, a highly sensitive and specific realtime PCR assay. Med Mycol. 2019 Feb;57(2):246-55. 
medRxiv preprint doi: https://doi.org/10.1101/2021.06.24.21258773; this version posted June 28, 2021. The copyright holder for this preprint (which was not certified by peer review) is the author/funder, who has granted medRxiv a license to display the preprint in perpetuity. It is made available under a CC-BY-NC-ND 4.0 International license .

71. Saubolle MA, Wojack BR, Wertheimer AM, Fuayagem AZ, Young S, Koeneman BA. Multicenter Clinical Validation of a Cartridge-Based Real-Time PCR System for Detection of Coccidioides spp. in Lower Respiratory Specimens. J Clin Microbiol. 2018 Feb;56(2).

72. Brown J, Benedict K, Park BJ, Thompson GR, 3rd. Coccidioidomycosis: epidemiology. Clin Epidemiol. 2013;5:185-97.

73. Bureau USC. The Desert Southwest.

74. Charles MA. Developmental origins of adult health and disease: an important concept for social inequalities in health. Rev Epidemiol Sante Publique. 2013 Aug;61 Suppl 3:S133-8.

75. Cunningham AA, Scoones I, Wood JLN. One Health for a changing world: new perspectives from Africa. Philos Trans R Soc Lond B Biol Sci. 2017 Jul 19;372(1725).

76. Marmot M. Economic and social determinants of disease. Bull World Health Organ. 2001;79(10):988-9.

77. Egede LE. Race, ethnicity, culture, and disparities in health care. J Gen Intern Med. 2006 Jun;21(6):667-9.

78. Collins FS. What we do and don't know about 'race', 'ethnicity', genetics and health at the dawn of the genome era. Nat Genet. 2004 Nov;36(11 Suppl):S13-5.

79. Museum AS. Federally Recognized Tribes in Arizona. 2021 [cited 2/20/21]; Available from: https://statemuseum.arizona.edu/programs/american-indian-relations/tribes-arizona

80. Health ADo. Population Health and Vital Statistics. 2021 [cited 02/20/2021]; Available from: https://pub.azdhs.gov/health-stats/menu/info/pop/index.php

81. Sievers ML. Disseminated Coccidioidomycosis among Southwestern American Indians. Am Rev Respir Dis. 1974;109(6):602-12.

82. Sievers ML, Fisher JR. Decreasing Incidence of Disseminated Coccidioidomycosis among Piman and San-Carlos Apache Indians - a Probable Environmental Basis. Chest. 1982;82(4):45560 .

83. Holman RC, Folkema AM, Singleton RJ, Redd JT, Christensen KY, Steiner CA, et al. Disparities in Infectious Disease Hospitalizations for American Indian/Alaska Native People. Public Health Reports. 2011 Jul-Aug;126(4):508-21.

84. Cheek JE, Holman RC, Redd JT, Haberling D, Hennessy TW. Infectious Disease Mortality Among American Indians and Alaska Natives, 1999-2009. American Journal of Public Health. 2014 Jun; 104:S446-S52.

85. Barton IS, Fuqua C, Platt TG. Ecological and evolutionary dynamics of a model facultative pathogen: Agrobacterium and crown gall disease of plants. Environ Microbiol. 2018 Jan;20(1):1629.

86. Suzuki SU, Sasaki A. Ecological and Evolutionary Stabilities of Biotrophism, Necrotrophism, and Saprotrophism. Am Nat. 2019 Jul;194(1):90-103. 